\title{
Sustainability Ranking of the UK Major Ports: Methodology and Case Study
}

Nasrin Asgari (Corresponding author)

Logistics and Operational Research Group,

Department of mathematics,

University of Portsmouth,

Lion Gate building,

Lion Terrace,

Portsmouth,

P01 3HF, UK

Email: Asgarin@gmail.com

\section{Ashkan Hassani}

Department of Industrial and Systems Engineering

Wayne State University

Detroit

MI

USA

\section{Dylan Jones}

Logistics and Operational Research Group,

Department of mathematics,

University of Portsmouth,

Lion Gate building,

Lion Terrace,

Portsmouth,

P01 3HF, UK

\section{Hoang Huy Nguyen}

Logistics and Operational Research Group,

Department of mathematics,

University of Portsmouth,

Lion Gate building,

Lion Terrace,

Portsmouth,

P01 3HF, UK

\section{Abstract}

Maritime supply chain sustainability has not been widely studied to date. This paper investigates the sustainability performance of five major UK ports. The UK port system is one of the largest and busiest port systems both in Europe and worldwide. The scope of sustainability narrows down to economical and environmental dimensions. A questionnaire is developed to collect data from port managers and logistics experts. The AHP method is utilized to 
rank the ports using the collected data. Sensitivity analysis is conducted on the obtained data to verify the consistency among data and outcomes.

Keywords: Supply chain sustainability; The UK port system; Environmental management systems; Multi criteria decision making; AHP.

\section{Introduction \& Background}

\subsection{Maritime Supply Chain}

The maritime industry with around $90 \%$ of global trade by volume and $70 \%$ by value is one of the most globalized and largest industry sectors in the world (Asgari et al., 2013). Different categories can be considered for maritime industry such as: maritime transportation, maritime logistics, and maritime supply chain.

Maritime transportation is only focusses on the transport of products that flow between two seaports by sea, while logistics integrates many activities to control the flow of products from supplier points to end customers (Song \& Panayides, 2012). Logistics can be defined as a part of supply chain. While logistic activities are only concerned about the management of material and information flow from supply points to demand points, the supply chain is wider in scope as it involes managing and coordinating the tasks of the whole chain. Supply chain management therefore includes the management of many key business aspects such as: transportation, material control, manufacture and distribution from supplier until the end customer (Harrison \& Hoek, 2008). Maritime transportation is considered as a linkage in this chain (Banomyong, 2005).

Two main sectors in the maritime supply chain are liner shipping and ports. Liner shipping plays the role of a customer for port systems. Ports play a key role in the maritime supply chain since they are loacted as the centre link between land and sea transportation for international trade. Processing 16,786 millions tons volume of cargoes in 2011, the port system has to deal with a huge demand of goods movement worldwide. Therefore, any significant improvement that can be achieved in its infrastructure and the quality of services will have a significant effect on the efficiency of maritime supply chains.

The new trend of worldwide maritime logistics is concerned not only about new developments in techniques, management and liberalization but also about creating more competition (Song \& Lee, 2009). Consequently, maritime logistics brings higher quality services to customers by conducting transportation in the supply chain in a more effective and efficient manner.

\subsection{Importance of Sustainability}

Supply chain sustainability is a combination of the economic, environmental and social dimensions of supply chain management (Carter \& Rogers, 2008). Figure 1 shows the interfaces between these dimensions. Accordingly, a 
sustainable supply chain can be defined as the management of information, operations, funds and resources in order to maximize economic efficiency, maximize social welfare and minimize environmental impacts (Denktas-sakar \& Karatas-cetin, 2012).

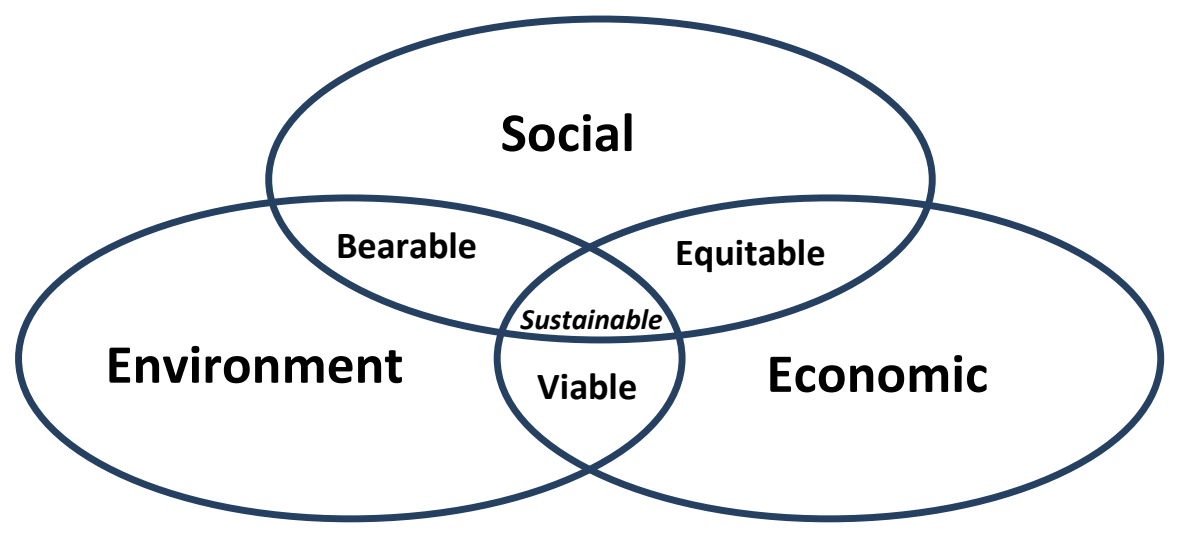

Figure 1. Sustainability Dimensions

In the recent years, sustainability has attracted a lot of attention from both the academic and industrial sectors. Regarding the economic and social dimensions, it aims to optimize the operations by improving costeffectiveness as well as the working conditions in the supply chain. On the other hand, the environmental aspect refers to reducing the associated negative environmetal impacts.

\subsection{Maritime Sustainability}

In recent years, the maritime industry has generally moved toward a sustainable supply chain which aims to improve the quality of logistics services as well as ensuring more wider benefits. Ports form an important part of any supply chain suistainibility considerations. Therefore, it is necessary to assess the sustainibility of ports in order to make optimal decisions and choose sustainable development strategies with regard to maritime supply chains.

In the maritime industry, all tasks are conducted in the context of a network of seaports. Products flow by transportation through this network. The economic aspect aims to optimize the operations, reduce costs such as fuel and shipping cost, and create value-added services. Besides that, the goal of the environmental aspect is to reduce negative environmental impacts. The social aspect plays an important role in sustainability as it aims to maximize the level of well-being in society. (Denktas-Sakar \& Karatas-Cetin, 2012)

\subsection{Literature Review and Gap Analysis}


There are a few studies in the literature in which the impact of sustainability in port management is studied. The main portions of these studies only consider the environmental aspect of sustainability. Goulielmos (2000), PerisMora et al. (2005), Le et al. (2014), and Villalba \& Gemechu (2011) are relevant examples. Gibbs et al. (2014) consider the emission from berths rather than ports. They analyze a set of UK ports in this study. Lu et al. (2012) consider the case of Taiwanese ports and assess the importance of sustainablity criteria.

Table 1 summarizes the related works and presents the problems, techniques, and achievements of each work. 
Table 1. List of literatures on maritime industy and port sustainability

\begin{tabular}{|c|c|c|c|c|}
\hline References & Maritime sustainability & Case/ Research study & Technique & Problem/ Achievements \\
\hline $\begin{array}{l}\text { Wooldridge et al. } \\
\text { (1999) }\end{array}$ & Port and harbor & Case study of UK ports & Mapping and monitoring protocol & $\begin{array}{l}\text { Evolve the environmental management protocols in } \\
\text { port areas by integrating policies, techniques. }\end{array}$ \\
\hline Goulielmos (2000) & Port environment & $\begin{array}{l}\text { Case study of European } \\
\text { ports }\end{array}$ & $\begin{array}{l}\text { Analysis of the function of port } \\
\text { production }\end{array}$ & $\begin{array}{l}\text { Determine the policy for port activities and } \\
\text { environment, control accidents, and prevent pollution } \\
\text { through international safety management code }\end{array}$ \\
\hline $\begin{array}{l}\text { Marlow \& Casaca } \\
\text { (2003) }\end{array}$ & Port performance & Research study & $\begin{array}{l}\text { Measure the lean port performance } \\
\text { (internal, external) towards an agile port }\end{array}$ & $\begin{array}{l}\text { Build up a framework to transform from lean port } \\
\text { performance to a dynamic network (agile ports) }\end{array}$ \\
\hline $\begin{array}{l}\text { Peris-Mora et al. } \\
(2005)\end{array}$ & $\begin{array}{l}\text { Sustainable port } \\
\text { management }\end{array}$ & $\begin{array}{l}\text { Case study ( Project } \\
\text { ECOPORT in Spanish and } \\
\text { European ports) }\end{array}$ & EMS ( ISO 14001) & $\begin{array}{c}\text { Develop an indicator system for the sustainability of } \\
\text { port management }\end{array}$ \\
\hline $\begin{array}{l}\text { Bichou } \\
(2004)\end{array}$ \& Gray & Port performance & Research study & $\begin{array}{l}\text { Analysis of the trade-off between cost } \\
\text { and customer satisfaction }\end{array}$ & $\begin{array}{c}\text { Establish a framework of port performance /improve } \\
\text { the efficiency and quality of logistics. }\end{array}$ \\
\hline $\begin{array}{l}\text { Fitzgerald et al. } \\
(2011)\end{array}$ & $\begin{array}{l}\text { International maritime } \\
\text { transport }\end{array}$ & Case study of New Zealand & $\begin{array}{c}\text { To calculate the amount of fuel } \\
\text { consumption and hence the greenhouse } \\
\text { gas emission }\end{array}$ & $\begin{array}{l}\text { Provide the results of fuel consumption and GHG } \\
\text { emission from import and export activities }\end{array}$ \\
\hline $\begin{array}{l}\text { Villalba \& Gemechu } \\
\text { (2011) }\end{array}$ & Maritime ports & $\begin{array}{l}\text { Case study of the port of } \\
\text { Barcelona }\end{array}$ & $\begin{array}{l}\text { Calculate the total amount of } \mathrm{CO}_{2} \\
\text { emission for both land and sea-side }\end{array}$ & $\begin{array}{l}\text { Estimate the amount of GHG emission and its sources } \\
\text { in the port. }\end{array}$ \\
\hline Lu et al. (2012) & International ports & $\begin{array}{l}\text { Case study of Taiwanese } \\
\text { Ports }\end{array}$ & Multi criteria decision making (MCDM) & $\begin{array}{l}\text { Assess the importance ranking of sustainable criteria } \\
\text { and port performance }\end{array}$ \\
\hline Le et al. (2014) & Port performance & $\begin{array}{l}\text { Case study of Vietnam and } \\
\text { Cambodia }\end{array}$ & $\begin{array}{l}\text { Environmental Management System } \\
\qquad(\text { EMS) }\end{array}$ & $\begin{array}{l}\text { Design a list of sustainable criteria for assessment/ } \\
\text { ranking the studied ports }\end{array}$ \\
\hline Gibbs et al. (2014) & Seaports & Case study of the UK ports & Interviews & $\begin{array}{l}\text { Calculate the emission of shipping from berths rather } \\
\text { than from the port }\end{array}$ \\
\hline This Research & Port Management & Case Study of the UK ports & AHP & $\begin{array}{l}\text { Port ranking based on both economic and } \\
\text { environmental aspects }\end{array}$ \\
\hline
\end{tabular}


Most studies in this area are case studies. But, what highlights the importance of this study is that to the best of our knowledge and shows in table 1, there is no study which considers both economic and environmental impacts simultaneously. Moreover, the gathered data for this study is primary data obtained from a survey of port and logistics experts.

Note that we investigate sustainability criteria in the United Kingdom port systems as a case study. The port system in the UK is one of the largest port systems in the world. It is ranked among top container exporter and importer in the world in 2009 and 2010, exporting 1.4 and 1.5 Million TEU (Twenty-foot Equivalent Units) and importing 2.3 and 2.5 Million TEU respectively. Table 2 depicts its ranking in the world and European Union based on TEU (World Shipping Council).

Table 2. The UK port system ranking (2010)

\begin{tabular}{|c|c|c|}
\hline & United Nations & European Union \\
\hline Import & 18 & 2 \\
\hline Export & 7 & 4 \\
\hline Total & 10 & 2 \\
\hline
\end{tabular}

As the UK port system is among largest ones in the world, this approach could be utilized for similar research on other port systems. Regarding that our data are secondary data, which achieved through surveys, we verify the results to make sure of its consistency with the secondary data available on ports.

This research tries to answer the following questions:

1. What are the criteria to evaluate maritime sustainability considering environmental and economic aspects?

2. What are the weights (relative importance) of each criterion/ sub-criterion?

3. What methodology is suitable to investigate ports sustainability performance? Why?

4. How can we verify the results extracted from secondary data?

The rest of the paper is organized as follows. Section 2 describes the UK maritime supply chain and its importance among other world port systems. Section 3 presents the problem statement. In Section 4, the research methodology is explained in detail and the research protocol is provided. Section 5 explains the primary data collection method, and using the gathered data, the proposed methodology is implemented. Section 6 provides some insights to validate the results. Section 7 concludes, and the limitations of this research and future direction are presented.

\section{The UK Maritime Supply Chain}

\subsection{The UK port authority}


There are more than 100 ports in the UK. The five largest ports in terms of tonnage are: Tees and Hartlepool, London, Grimsby and Immingham, Southampton, and Milford Haven, totally handling more than 200 million tons per year. Oil products account for a major part in the total volume accounting for half of total trading volume in UK ports. The port industry is a vital part in UK's economy. The port system in the UK is mostly governed by port authorities and companies such as Port of London Authority, British Ports Association (BPA) and Brookfield Ports Company (PD Ports).

A port authority is regarded as an entity which has responsibility to administer and manage all port facilities and infrastructures, as well as control all activities in the port. The governance of port authorities is under national law (Verhoeven, 2010). Nowadays, the demand for port operations in the UK arises from not only from the international but also from the local communities. It is expected the UK ports will be expanded in size, number of locations, and infrastructure to adapt to a higher demand in international trading and domestic services. As well safety, legislation, technical and environmental standards are expected to enhance the quality of the port's system. Regarding sustainability, port authorities have the responsibility to guide the port operations toward this trend. To be successful in sustainable development, the port authorities have to develop new strategies and policies which ensure the integration of the economic, social and environmental dimensions. Since 2002, Britain's leading ports operator has started to reform the framework of environmental management. These changes in policies are designed to achieve the following sustainable development related objectives:

- Reduce environmental damages from port operations

- Achieve efficiency in using natural resources

Following the trend of sustainable development, Brookfield Ports Company (PD Ports) has made more efforts to prevent environmental pollution and improve environmental management system toward ISO 14001 certification. In the environmental policy, the role of law, training and energy-efficiency is more concentrated.

\subsection{The UK Ports}

There are 120 ports in the UK which are distributed throughout the country providing different types of service. The port system in the UK is the second largest one in Europe with a significant amount of shipping: about 560 million tons per year, where $80 \%$ of that is handled by the top 16 ports (Baird \& Valentine, 2006).

None of the UK ports are government owned. Two kinds of Port management in the UK exist:

- All large ports are owned by the private sector and included in the group of ports that belong to the Association British Ports (ABP) such as: Forth, Tee \& Hartlepool, Felixstowe and Liverpool.

- The ports are owned by a trust. These ports are independent from the government and shareholders such as: London Authority. 
The environmental dimension, maritime life and security of ports have been the target of significant attention in recent years and these have become the main targets for future development (The UK Ports Industry - A profile, 2008). Environmental issues become significantly more important in sustainable strategies of port administration as the serious threat from global climate change becomes better known and understood.. There are two factors which are able to create economic value for ports: port location and port authorities.

This study is scoped to include the group of the five largest ports in the UK which are ranked regarding the volume of total traffic in Figure 2. These statistics are obtained for the 30 major ports in UK. The group of 5 largest ports takes $44 \%$ of total port traffic. Brief information of these five ports is presented in Table 3 . Figure 3 shows the location of these five ports on the map of the UK (GOV.UK, 2012).

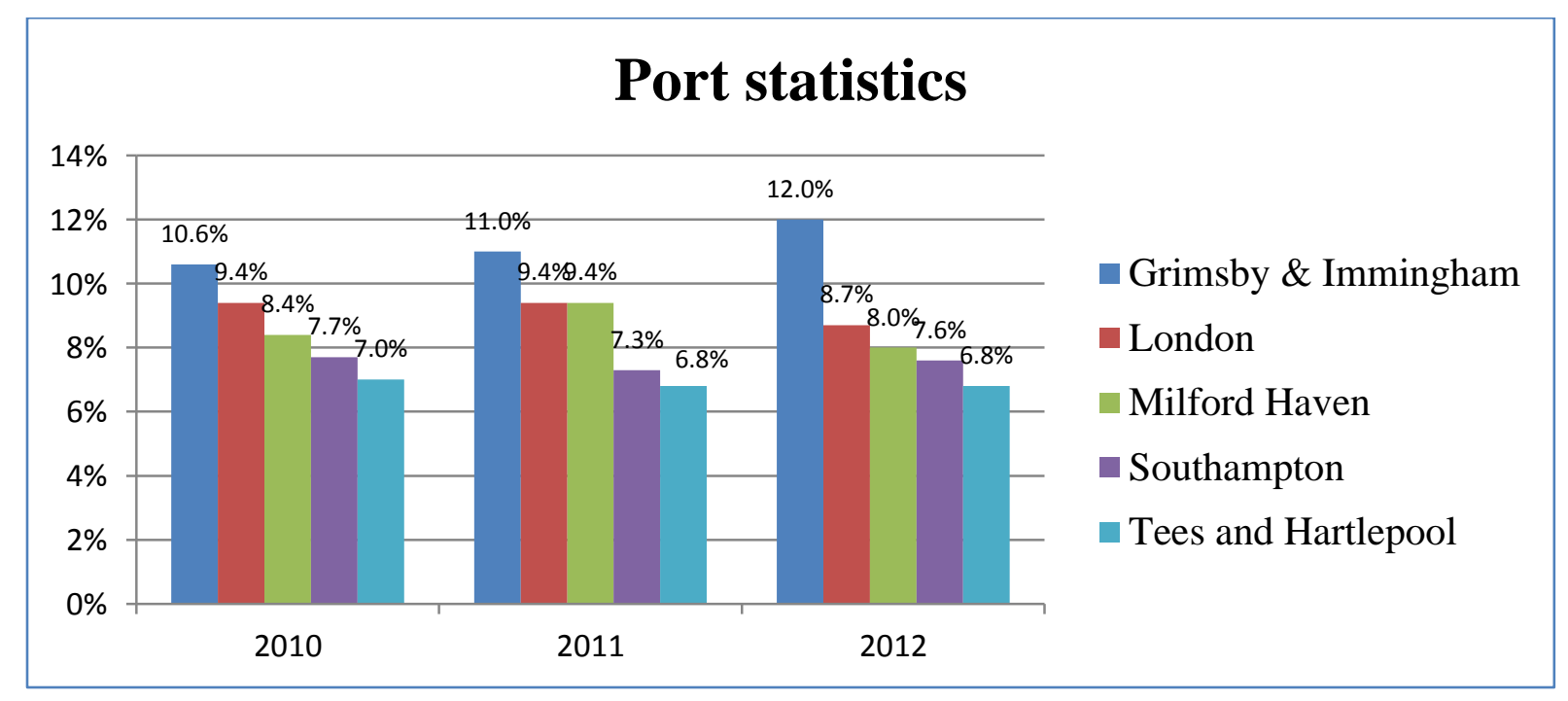

Figure 2. The traffic volume of five major ports in UK

(Source: https://www.gov.uk/government/collections/maritime-and-shipping-statistics)

Table 3. Brief information of major UK ports

\begin{tabular}{|c|l|l|}
\hline No. & \multicolumn{1}{|c|}{ Port and group Ports } & \multicolumn{1}{c|}{ Location } \\
\hline & & $\begin{array}{l}\text { This group of ports is considered as the center of the UK and Europe, } \\
\text { which is developed in the integration of 2 UK largest ports: Grimsby and } \\
\text { Immingham. The combination of 2 UK largest ports brings a huge capacity } \\
\text { for this region. } \\
\text { Immingham port is mainly specialized in logistics and services for local } \\
\text { industry (It can connect with Iceland, The Baltic, Rotterdam and } \\
\text { Scandinavia (Immingham). } \\
\text { Grimsby port: is named as the food town of Europe because the food } \\
\text { industry and fishing (it supplies 20000 tonnes of fresh fish per year) are the }\end{array}$ \\
\hline
\end{tabular}




\begin{tabular}{|c|c|c|}
\hline & & $\begin{array}{l}\text { focal point of this port (Grimsby). } \\
\text { The Grimsby and Immingham port provides the access to international } \\
\text { trading routes through North and South America, Africa, Europe, Middle } \\
\text { East, Australia and Far East. }\end{array}$ \\
\hline 2 & London & $\begin{array}{l}\text { One of three main functions of London port is inter Port trade. There are } \\
\text { totally } 70 \text { terminals which are connected in the shipping network with } 80 \\
\text { countries (Port of London Authority, 2013). The Port of London is located } \\
\text { by the River Thames, to the northeast of Southampton Port. }\end{array}$ \\
\hline 3 & Milford Haven & $\begin{array}{l}\text { The biggest port is located in Wales, which specializes in the trading of oil } \\
\text { and gas (Environmental Performance Report, 2012). Thus, this port is } \\
\text { connected in two main trading routes: tanker routes from Qatar, Asia } \\
\text { Pacific, West Coast and UK pipeline network from Algeria, Malaysia, } \\
\text { Trinidad and Egypt (Q\&A: Liquefied natural gas, 2009). }\end{array}$ \\
\hline 4 & Tees and Hartlepool & $\begin{array}{l}\text { This is a combination of the port systems of Teesport and Hartlepool, } \\
\text { which are located on the north-east coast of England. } \\
\text { - Teesport: it is located next to the mouth of River Tees and lock-free } \\
\text { connects with the North Sea. Thus, it receives } 5000 \text { vessels and } 34 \\
\text { million tones cargo per year. } \\
\text { Hartlepool port: it is located three miles from the River Tees. It has free } \\
\text { access to the sea and North Basin. The port specializes in the sectors } \\
\text { of oil, gas, wind energy, and bulk cargo. (TEESPORT AND } \\
\text { HARTELPOOL PORT HANDBOOK, 2013) }\end{array}$ \\
\hline 5 & Southampton & $\begin{array}{l}\text { This port is located in the south coast of UK. This is one of the busiest } \\
\text { ports in the country. This port handles the product flows which come from } \\
\text { Far East to Britain, particularly container traffic. It is also the largest } \\
\text { import export hub of motor vehicles in the country (Port of Southampton, } \\
\text { The UK's most dynamic gateway, 2013). }\end{array}$ \\
\hline
\end{tabular}

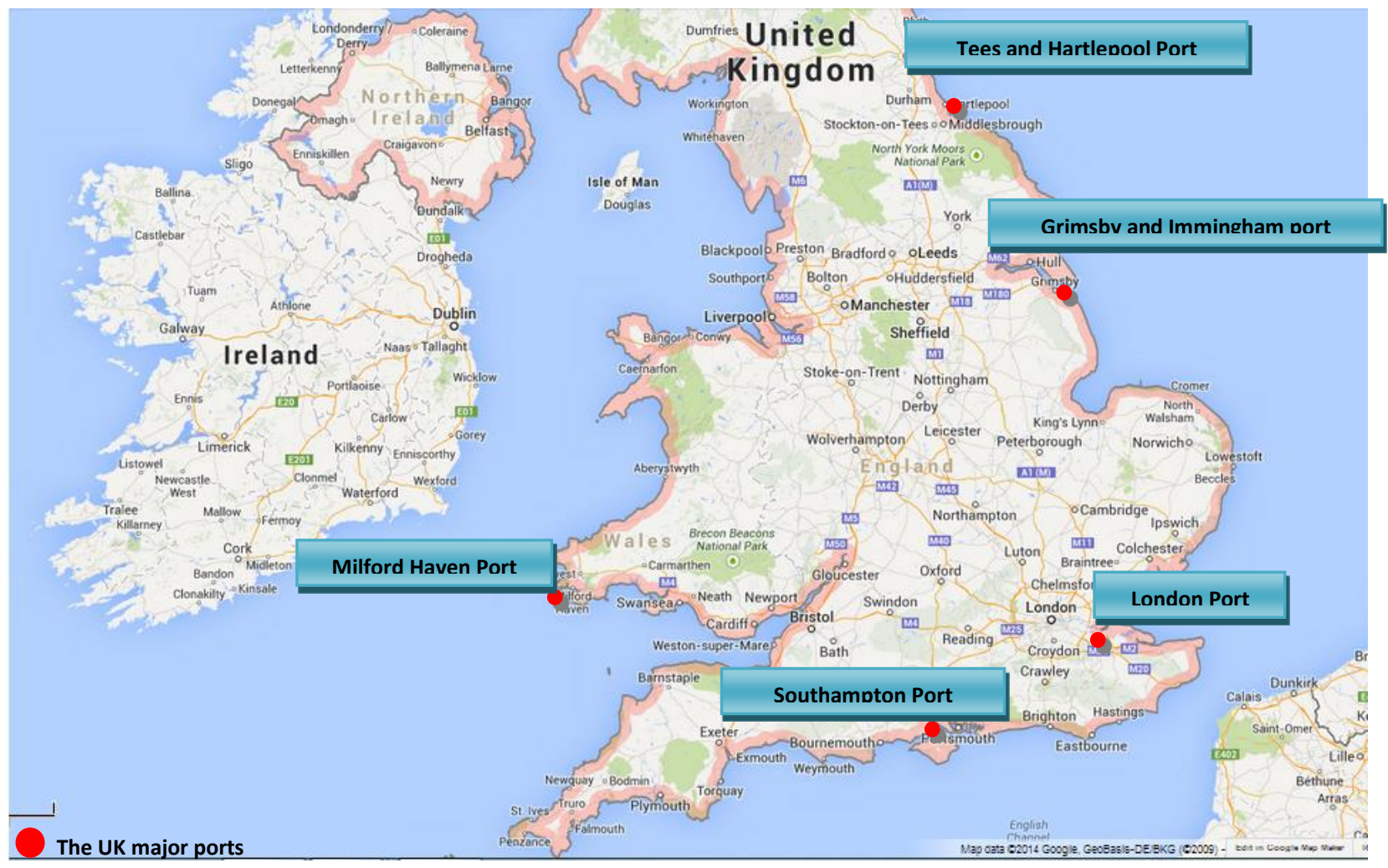

Figure 3. Location of the 5 top ports of the UK

\subsection{The sustainable performance of UK ports:}


In 2013, environmental issues in the UK had a high level of visibility with a lot of green port-related projects undertaken. For example, the project of new port London gateway premiered at the end of 2013, which is built with the goal of being an environment-friendly port. This port is built on the philosophy of an effective combination of economic and environmental goals.

There are three certifications used for improving sustainable performance in ports: ISO 14001, Green Ports and Ecoports.

- ISO 14001: this is a group of management system standards that are applied to improve the environmental performance in organizations. These standards exist in order to assess, organize and reorganize towards sustainable development in business organization. They help to reduce pollution from each part of the system (Saengsupavanich et al. 2009).

- Green Ports: a certification that shows balancing between environmental protection and economic demand. It aims to provide new environmental solutions for ports and terminals.

- Ecoports: This is integration between two concepts: effective environmental and port management. It is mostly applied for ports in Europe (ESPO/Ecoports)

In this paper, the standards of 14001 are applied for sustainable assessment of the port group as they are the most general, and hence appropriate for this study. After that, the port ranking is established which aims to assess the success of their efforts in sustainable development.

\section{Problem Statement}

\subsection{Problem Description}

The UK port system is an integral sector for the economic growth of the country; so good policy making is very important to manage this system. As mentioned earlier, the UK port system is the second largest in the EU with a large annual trade, and it is independent of government control. Therefore, factors which make this system a modern port system in European zone are the topic of ongoing investigation (Asteris and Collins, 2010). Recently, sustainability has become an important standard to assess port activities. An analysis of the entire UK port system analysis with 120 ports and wide ranges of activities would be very complex and lead to a lack of

focus due to the diverse nature of the activities; therefore, this study concentrates on the five largest ports in this country, which own a significant portion of the trading volume (44\% of total port traffic).

In this study, the concept of sustainability is analyzed considering two dimensions: economic and environmental. This aims to show the core responsibility of policy and strategy making not only to achieve more 
cost-benefits but also to create more innovations and environmental friendly management techniques. Such factors are very important for sustainable long term development.

In this study, a list of indicators about economic and environmental dimensions is established from port activities. From those indicators, the set of criteria is applied to assess the sustainable performance of the UK port industry. A multi criteria decision making (MCDM) method is utilized to rank each alternative among the group of chosen ports which achieve efficiently a suitable balance between economic and environmental objectives.

The top 5 selected ports are located in different regions in the UK. In Table 4, related information is presented. As shown, these ports have a good performance in sustainability which is approved through different certifications on environmental management. This shows the effort of port administrations in investing in sustainable development. 
Table 4. Selected Ports Information

\begin{tabular}{|c|c|c|c|c|c|c|c|}
\hline Port name & Port location & $\begin{array}{l}\text { Capacity (Million } \\
\text { tons cargo/ year) }\end{array}$ & Port Authority & $\begin{array}{c}\text { Greenhouse gas } \\
\text { emission (CO2 } \\
\text { equivalent tons) }\end{array}$ & Green Port & $\begin{array}{l}\text { ISO } 14001 \\
\text { (EMS) }\end{array}$ & $\begin{array}{l}\text { Other Green } \\
\text { Certifications }\end{array}$ \\
\hline \begin{tabular}{|l} 
Grimsby and \\
Immingham
\end{tabular} & $\begin{array}{l}\text { The river } \\
\text { Humber }\end{array}$ & 55 & PD port & & $\checkmark$ & & Ecoport \\
\hline London & $\begin{array}{l}\text { The river } \\
\text { Thames }\end{array}$ & 53 & London Port & 1772 (2011) & $\checkmark$ & & Ecoport \\
\hline Milford Haven & $\begin{array}{c}\text { South West } \\
\text { Wales }\end{array}$ & 35 & $\begin{array}{l}\text { Milford } \\
\text { Heaven }\end{array}$ & & $\checkmark$ & & Ecoport \\
\hline Southampton & $\begin{array}{l}\text { Central South } \\
\text { Coast }\end{array}$ & 39 & $A B P$ & & & & \\
\hline $\begin{array}{ll}\text { Tees } & \text { and } \\
\text { Hartlepool } & \\
\end{array}$ & River Tees & 56 & PD Ports & & & & \\
\hline
\end{tabular}

\subsection{Objectives}

With regard to the maritime supply chain, this study is scoped to assess the sustainable performance of the 5 largest UK ports. The assessment includes economic and environmental dimensions.

\section{- Economic goals:}

Ports are an integral part in the supply chain design related to achieve cost-efficiency goals from optimizing operation costs. Economic aims are to minimize operation costs such as: transportation cost, shipping cost and inventory cost. In addition, the quality of services is also an important criterion to attract more customers such as: reduce the service and waiting time and reduce port congestion.

\section{- Environmental goals:}

These aim to decrease environmental impacts from both port and shipping operations in the port area. A set of environmental indicators is designed to measure pollution degrees, environmental legislations, renewables and the strategies of future development.

Accordingly, the list of criteria is designed following the standards of environmental management system (EMS) ISO 14001 and previous research. In corresponding to each criterion, there are the indicators which are measured to evaluate the port performance using the criteria.

\section{Sustainable Criteria and Indicators}

In the first step, a set of economic and environmental criteria and indicators are considered. To do so, we used environmental management systems standards (ISO 14001) and UK ports authority. ISO 14001 is a certification of environment management system (EMS). It provides a framework for organizations to undertake the efforts of reducing environment impacts and continuous improvement. It is also a good standard to develop a system for sustainable assessment. 
In addition, a set of environmental and economic indicators is needed. In correspondence to these criteria, a set of indicators is determined by following steps (Peris-Mora et al., 2005):

- Determine impacts of the indicator on the process

- Evaluate the levels of such impacts

- Examine the relation among impacts

Permala (2009) presented a potential indicator set for the economic, environmental, and social domains. This set is utilized to assess the criteria. The main objectives to develop sustainability in port performance are:

- To reduce negative effects on the air, noise and marine environments.

- To exam the port policy to reduce the environmental impacts

\section{Methodology}

\subsection{Multi Criteria Decision Making (MCDM)}

MCDM methodology is a paradigm which supports decision makers by considering a set of relevant criteria. This methodology is classified to two different types: multi-objective decision making (MODM) and multiattribute decision making (MADM). According to Mendoza \& Prabhu (2000) MADM ranks alternatives based on a set of discrete criteria and generated discrete solutions.

First, a set of alternatives is determined along with a number of attributes, considering the objective. In MADM, a comparison matrix is developed where rows are the desired choices and columns are set of attributes.

\section{Inputs}

$Z_{i}$ : Set of attributes, obtained from the decision environment, $i=\{1,2,3 \ldots K\}$

$X_{j}$ : Set of alternatives (choices), defined for evaluation, $j=\{1,2,3 \ldots . N\}$

$W_{i}$ : Set of weights for each attribute, $i=\{1,2,3 \ldots K\}$

Objective function:

$$
\text { Optimize } Z=f\left(x_{1}, x_{2}, x_{3}, \ldots, x_{n}\right)=\sum_{i} w_{i} f\left(x_{i}\right)
$$

This method can solve complex problems with different objectives, information, benefit and data. Therefore, MADM is hence suitable to evaluate socio-economic problems such as sustainability-related problems. 
Figure 4 summarizes the MADM steps to compare attributes. According to MADM, the objectives are an origin of processes in the diagram. From the main objectives, a group of potential alternatives is selected. We need to identify a set of attributes. After that, the set of attributes is weighted to determine their importance. Lastly, they are normalized for comparison between criteria.

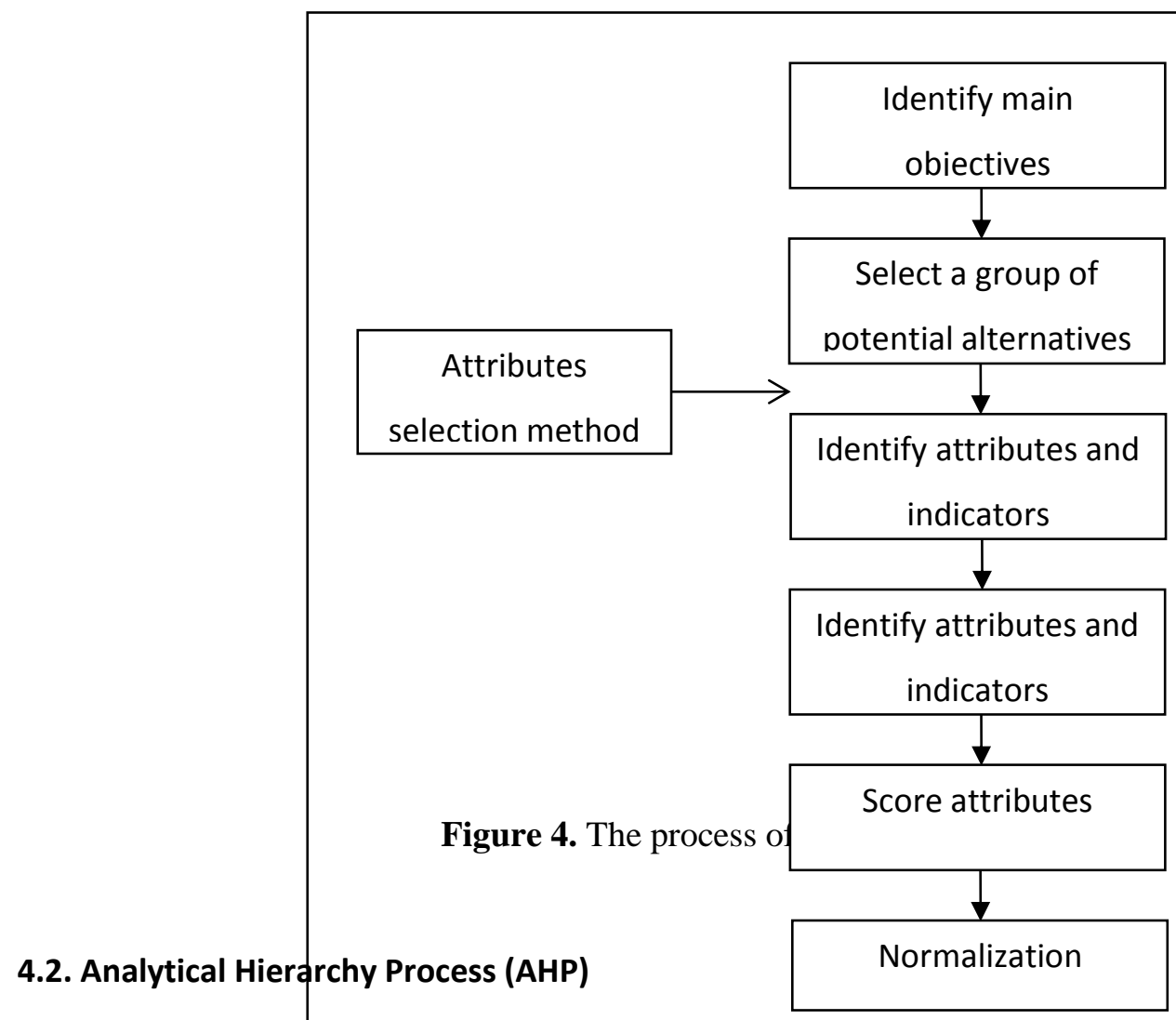

The analytic hierarchy process (AHP), proposed by Saaty, 1988, is a powerful tool which supports decision making in a multi-attribute environment. The inputs and objectives are the same as those of MCDM. According to Ramanathan (2001), the AHP method is considered as a powerful tool for environmental impact assessment (EIA) for many reasons:

This method can assess the trade-offs between environmental and economic impacts.

$>$ The experts' point of views on the problem can be collected through surveys that only require pairwise comparisons between two criteria at a time.

$>$ A consistency test exists that ensures the quality of judgments

Another advantage of this method is that it helps to reform the expert opinions into a numerical scale; however, it has to be checked with consistency ratio to ensure of the survey's quality.

Firstly, AHP decomposes the decision problem into a hierarchy of more easily comprehended subproblems, each of which can be analyzed independently. The elements of the hierarchy can relate to any aspect of the decision problem. Figure 5 depicts this process. 


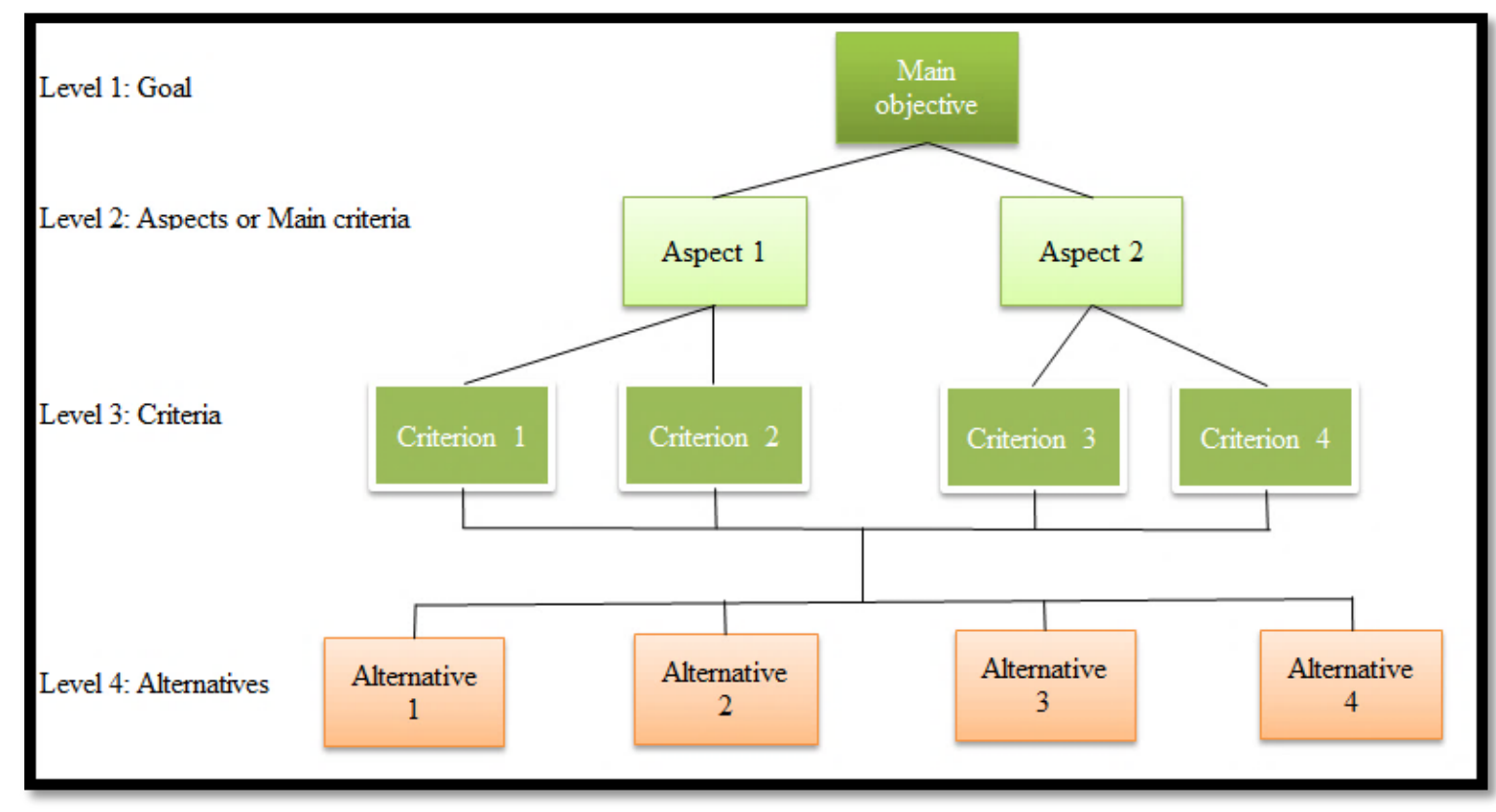

Figure 5. The decision hierarchy diagram

In second step, the weights for attributes are computed. It starts with the comparison matrix $(k \times k)$, where $k$ is the number of attributes, and then sets it up the scale to assess the importance of attributes. The value of each entry is denoted by $a_{i j}$ as shown in Figure 6.

\begin{tabular}{|c|c|}
\hline Attributes & $\begin{array}{llll}Z_{1} & Z_{2} Z_{3} & \ldots & Z_{k}\end{array}$ \\
\hline $\begin{array}{c}Z_{1} \\
Z_{2} \\
Z_{3} \\
\vdots \\
Z_{k}\end{array}$ & $A=\left[\begin{array}{ccccc}1 & a_{12} & a_{13} & \ldots & a_{1 k} \\
a_{21} & 1 & a_{23} & \ldots & a_{2 k} \\
a_{31} a_{32} & 1 & \ldots & a_{3 k} \\
\vdots & \vdots & \vdots & \ddots & \vdots \\
a_{k 1} a_{k 2} & a_{k 3} & \ldots & 1\end{array}\right]_{k \times k}$ \\
\hline
\end{tabular}

Figure 6. Pairwise comparison matrix

$a_{i j}$ is calculated according to Table 5 .

Table 5. The comparison scale in AHP method

\begin{tabular}{|c|l|}
\hline Value of $\boldsymbol{a}_{\boldsymbol{i}}$ & \multicolumn{1}{|c|}{ Important levels } \\
\hline $\mathbf{1}$ & Attribute $i$ and $j$ are equal important \\
$\mathbf{3}$ & Attribute $i$ is weakly more important than $j$ \\
$\mathbf{5}$ & Attribute $i$ is strongly more important than $j$ \\
$\mathbf{7}$ & Attribute $i$ is very strongly more important than $j$ \\
$\mathbf{9}$ & Attribute $i$ is absolutely more important than $j$ \\
$\mathbf{2 , 4 , 6 , 8}$ & Give the intermediate values. \\
\hline
\end{tabular}

$a_{j i}$ can be simply obtained using: 


$$
a_{j i}=\frac{1}{a_{i j}}
$$

In the last step, consistency index is determined to assess how the consistency of the decision makers' comparison is. We refer interested readers to (Saaty 1998).

\section{Score the set of alternatives performance}

Along with weighting of attributes, score calculation of each alternative is also very important. While weighting is used to determine priority for attributes (or criteria), scores are used to select alternatives.

Step 1: Develop pairwise comparison matrix for a group of alternatives based on their importance to assess the value of $a_{i j}$.

Step 2: Calculate $W_{i j}$ as follows:

$$
W_{i j}=\frac{a_{i j}}{\sum_{i=1}^{n} a_{i j}}
$$

Step 3: These weights create a new matrix $\left(A_{\text {norm }}\right)$

$$
A_{\text {norm }}=\left[\begin{array}{cccccc}
\frac{W_{1}}{W_{1}} \frac{W_{1}}{W_{2}} \frac{W_{1}}{W_{3}} & \ldots & \frac{W_{1}}{W_{k}} \\
\frac{W_{2}}{W_{1}} & 1 & \frac{W_{2}}{W_{3}} & \ldots & \frac{W_{2}}{W_{k}} \\
\frac{W_{3}}{W_{1}} \frac{W_{3}}{W_{2}} & 1 & \ldots & \frac{W_{3}}{W_{k}} \\
\vdots & \vdots & \ddots & \vdots \\
\frac{W_{k}}{W_{1}} \frac{W_{k}}{W_{2}} \frac{W_{k}}{W_{3}} & \ldots & 1
\end{array}\right]
$$

The weight of each alternative is the average of weights in each row which can be considered as the score of alternatives. The alternative that has the highest score is the optimal solution. Figure 7 summarizes the AHP steps.

In this study, the Expert Choice software package is utilized. The software is based on the theory of AHP. By inserting the obtained data from the survey, the AHP method derives weights for the criteria and scores for alternatives based on three types of comparison scales: numeral, verbal and graphical. The verbal comparison the most commonly used with nine levels from equal to extremely more important. 
Figure 7. The processing steps of analytic hierarchy process (AHP) method

\subsection{Research Protocol}

Considering to the field of sustainability, it is difficult to integrate the economic and environmental dimensions together since they are conflicting in their targets (Gilman, 2003). This is mainly because all economic strategies aim to bring more cost-efficiency by optimizing port operations, while most environmental strategies normally require a lot of investment. Therefore, it is very difficult to balance these dimensions that are the main goals of sustainability towards future development. A set of criteria is hence established to evaluate the performance and competiveness of each port.

According to AHP, the first step is to develop the decision hierarchy. We develop the hierarchies of environmental aspect based on the ISO 14001, standards of environmental management systems. ISO 14001components are presented in Appendix A.

The research protocol is presented in Figure 8. All inputs and steps of the proposed methodology are depicted in this Figure. 


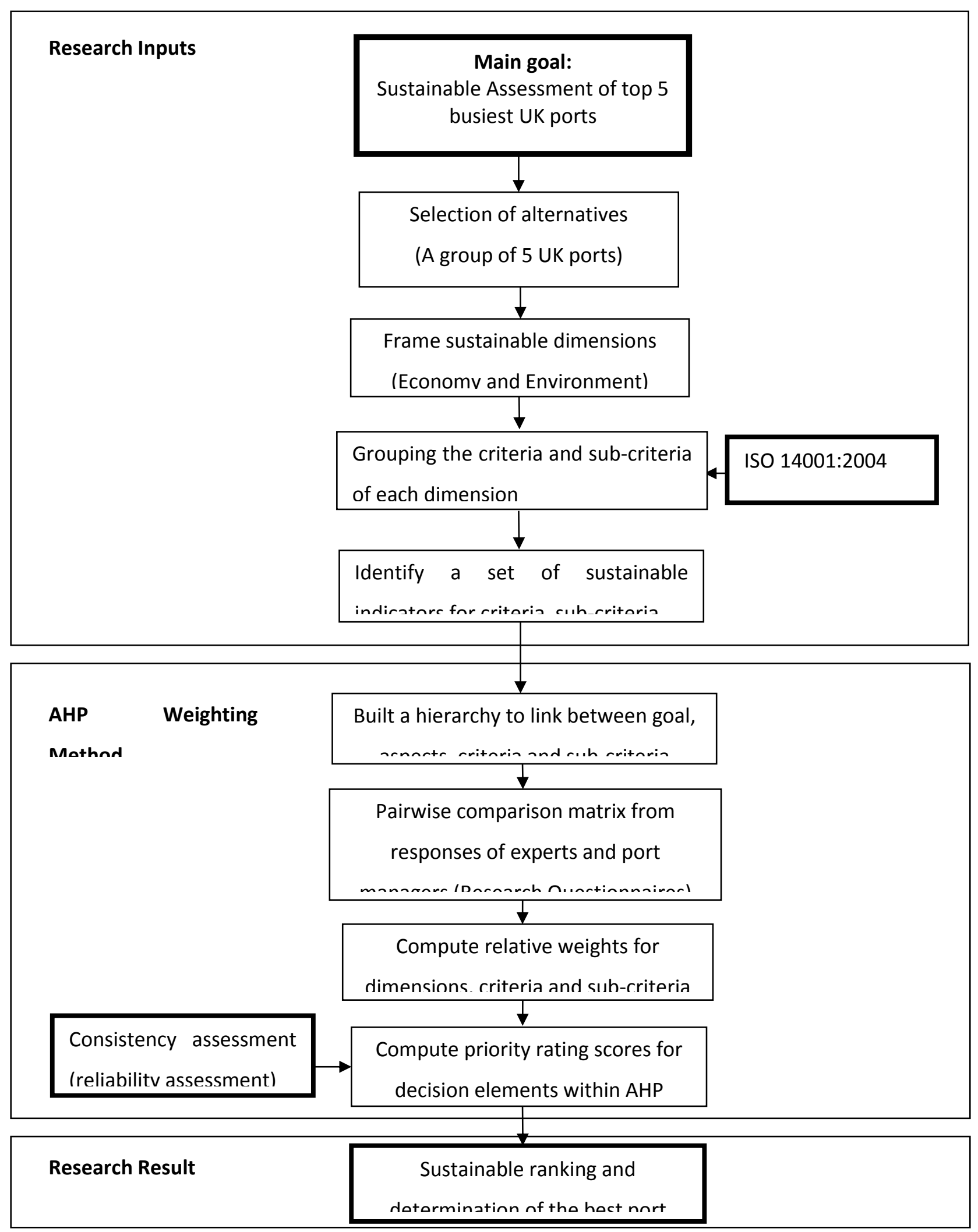

Figure 8. Research Protocol Diagram

\section{Implementation}

\subsection{Data}


In order to rank the ports based on their sustainability performance, a survey is conducted based on two factors: the set of selected ports (alternatives) and the set of attributes (criteria). In order to collect data we follow the following steps:

\section{(i) Participants selection}

There are two types of participant who need to be invited: port managers and logistics experts. Port managers are the ones who develop strategies and policies toward sustainability. They directly control the port system to satisfy the desired targets. Logistics experts are ones who teach, work and research in this area, so they have valuable experiences and knowledge to evaluate the set of criteria and alternatives. They know the differences between ports. While port managers can evaluate the practical implementation of sustainable approaches and their effects in internal port organization, logistics experts who have a general view and knowledge of the UK port system can evaluate the effects of each attribute on each selected port precisely. All of the participants have to be people with local and port-related knowledge.

The surveys are sent to both port managers and logistics experts. 10 surveys in two types: online and checkbox form are sent by email to port managers. Moreover, forms are sent to 2 academic logistics experts.

\section{(ii) Questionnaire survey}

After determining the participants, the survey is designed with questions aimed to reflect the specified targets. For each criterion, the set of ports is evaluated by the importance level following the previously described 1-9 scale. The structure of the questionnaire is as follows:

First of all, a set of questions aim to collect general information about environmental management system (EMS) as well as questions on applying the standards of ISO 14001 to improve sustainability. The main objective of this part is general understanding of sustainable development in each port, which will be reflected by policies and strategies.

Next, the most important part is to consult with the personal experiences and opinions of the port performance under a set of sustainable criteria. The assessment uses scale of 9 significant levels. Lastly, the ranking questions aims to evaluate the port performance according to the given set of multiple criteria. It is the base to score alternatives in correspondence to each criterion. The form of the questionnaire survey is provided in Appendix B.

\subsection{Decision hierarchy formulating}

After collecting data from surveys, the AHP is utilized in order to determine the priorities of the criteria. Table 6 presents the decision hierarchy in the questionnaire:

Table 6. Decision hierarchy 


\begin{tabular}{|c|c|c|c|}
\hline Main objective & Dimensions & Criteria & Sub-criteria \\
\hline $\begin{array}{l}\text { Sustainable } \\
\text { performance in UK } \\
\text { ports }\end{array}$ & $\begin{array}{l}\text { Environmental } \\
\text { aspect }\end{array}$ & $\begin{array}{l}\text { 1. Establish } \\
\text { environmental } \\
\text { policies } \\
\text { 2. Identify } \\
\text { environmental } \\
\text { impacts } \\
\text { 3. Environmental } \\
\text { objectives and } \\
\text { priorities } \\
\text { 4. Environmental } \\
\text { dimension } \\
\text { 9. Cost-efficiency } \\
\text { High quality of } \\
\text { services } \\
\text { 5. Commitment } \\
\text { identification } \\
\text { 6. Training and } \\
\text { awareness } \\
\text { preparedness and } \\
\text { response }\end{array}$ & $\begin{array}{l}\text { 4.1 Identify categories of } \\
\text { environmental pollution } \\
\text { 4.2Waste management } \\
\text { 4.3Energy consumption } \\
\text { 7.1To minimize damages of } \\
\text { environment } \\
\text { 7.2 Environmental risk } \\
\text { management }\end{array}$ \\
\hline
\end{tabular}

Table 6 depicts the hierarchy development from main the main goal which is sustainable port performance for the set of criteria. In the second level, it shows two aspects of this study: economic and environmental. Next, a set of criteria is developed to measure the performance in each dimension. A set of environmental criteria is designed from ISO 14001. Besides that, as mentioned earlier, the economic dimension is also very important in the context of sustainability. With regard to sustainability, there are two sub-criteria that need to be considered: cost-efficiency and high quality service. The set of indicators for both economic and environmental aspects are provided in Appendix $C$.

\subsection{Pair-wise Comparison matrix}

After the decision hierarchy is designed with four levels, the pairwise matrix is established to compare the pairs of criteria together at the same level. There are two ways to evaluate the criteria: 
- Top-down: This way is developed from the top level (goal) to lower levels.

- Bottom-up: In opposition, the comparisons are made from the alternatives.

In this study, the criteria evaluation follows "top-down" approach. As it can be seen from the decision hierarchy, there are totally four levels of objectives as shown in Table 7.

Table 7. The hierarchy description

\begin{tabular}{|c|l|}
\hline Levels & \multicolumn{1}{c|}{ Description } \\
\hline 1 & Main goal/ objective \\
\hline 2 & Main criteria of two aspects: environment and economy \\
\hline 3 & Two set of criteria which are developed from two main criteria. \\
\hline 4 & The sub-criteria are made from upper-criteria. \\
\hline 5 & The set of alternatives (ports) \\
\hline
\end{tabular}

Entries of the comparison matrix are calculated as formula below:

$$
\frac{n \times(n-1)}{2}
$$

Where:

$n=$ the number of criteria or alternative in a comparison matrix $(n \geq 2)$ (Ishizaka \& Labib, 2011)

According to this formulation, Table 8 presents the number of entries required in each level.

Table 8. The entries for pairwise comparison

\begin{tabular}{|c|c|}
\hline Level & Entries \\
\hline 2 & 1 \\
\hline 3 & 36 \\
\hline 4 & 120 \\
\hline Total & 147 \\
\hline
\end{tabular}

There are totally 147 entries required for this decision hierarchy. As a case in point, in level two, since there are 2 main criteria, we require one entry in comparison matrix. Table 9 shows this fact.

Table 9. The pairwise comparison matrix

\begin{tabular}{|l|c|c|}
\hline Main criteria & Environmental aspect & Economic aspect \\
\hline Environmental aspect & 1 & \\
\hline Economic aspect & & 1 \\
\hline
\end{tabular}

There are two types of comparison in level 3:

Cluster comparison: This compares two clusters separately. A criteria cluster is defined as a set of criteria or sub-criteria which is developed from one criterion of its upper level. 
This comparison aims to assess the priorities of criteria in each cluster. There are two set of sub-criteria which require comparison matrices.

Table 10. The pairwise comparison matrix of the first cluster in level 3

\begin{tabular}{|c|c|c|c|c|c|c|c|}
\hline Criteria & 1 & 2 & 3 & 4 & 5 & 6 & 7 \\
\hline 1 & 1 & & & & & & \\
\hline 2 & & 1 & & & & & \\
\hline 3 & & & 1 & & & & \\
\hline 4 & & & & 1 & & & \\
\hline 5 & & & & & 1 & & \\
\hline 6 & & & & & & 1 & \\
\hline 7 & & & & & & & 1 \\
\hline
\end{tabular}

Table 10 represents the comparison matrix for the environmental dimension, and Table 11 depicts this matrix for the economic dimension.

Table 11. The pairwise comparison matrix of the second cluster in level 3

\begin{tabular}{|c|c|c|}
\hline Criteria & 1 & 2 \\
\hline 1 & 1 & \\
\hline 2 & & 1 \\
\hline
\end{tabular}

Level comparison: This comparison aims to do evaluation among all criteria in the same level. This study concentrates on this type of comparison, because it provides a general assessment on combination of two dimensions of sustainability.

The structure of questionnaires contained three parts:

- Part A aims to collect the participant's profile.

- Part B contained questions related to the ISO 14001 of environmental management system (EMS). It is mainly because a majority of criteria and sub-criteria are designed from the standards of this certification.

- Part $C$ is the main part used to gather all evaluations of participants by ranking. The participants have to rank all criteria using 1 to 9 scale. After the criteria evaluation, the ports are scored based on each criterion and sub-criterion.

\subsection{Results}

Criteria or attributes in the same cluster are ranked based on the normalized weights. As well, the process of calculating follows the level. Therefore, if there are two clusters of criteria at the same level, they are ranked separately. The main target of the two comparison method is as follows: 
- In each cluster, the ranking of the cluster is made to prioritize the set of criteria within one cluster. This aims to evaluate the relative level of importance of each criterion under one aspect.

- The second type of comparison is carried on the level. This aims to make overall prioritization and ranking of all criteria in each level. The outcomes of this evaluation show the combination of two aspects in one assessment. That is reason why the method can be applied to evaluate the combination of aspects which are conflicting.

In addition, a consistency test is done using Expert Choice software. During the time of evaluation, each participant is checked by the ratio of consistency (inconsistency). The acceptable of consistency ratio is less than or equal to 0.1 .

Table 12 presents the relative weights which are obtained from the evaluations of both environmental and economic aspects. All criteria are ranked using a numeral scale: 1 is the most preferable. Regarding the evaluation, the environmental aspect has higher priority than economic aspect in the ranking with a mean weight of $52.95 \%$.

Table 12. The results of comparison in both environmental and economic aspect

\begin{tabular}{|l|c|c|c|c|c|c|c|}
\hline \multicolumn{1}{|c|}{ Criteria } & Participant 1 & Participant 2 & Participant 3 & Participant 4 & Participant 5 & Mean & Rank \\
\hline Environmental aspect & $31.89 \%$ & $54.99 \%$ & $66.67 \%$ & $36.19 \%$ & $74.99 \%$ & $52.95 \%$ & 1 \\
\hline Economic aspect & $68.11 \%$ & $45.01 \%$ & $33.33 \%$ & $63.81 \%$ & $25.01 \%$ & $47.05 \%$ & 2 \\
\hline
\end{tabular}

Table 13 depicts that the cost-efficiency criterion as the most important one compared to the other criteria in this level with a mean weight of $26.42 \%$. High quality services and identify environment objectives are ranked as the second and third most important ones in this level with $20.64 \%$ and $13.16 \%$, respectively.

Table 13. The weights of criteria in level 3 of decision hierarchy

\begin{tabular}{|l|c|c|c|c|c|c|c|}
\hline \multicolumn{1}{|c|}{ Criteria } & Participant 1 & Participant 2 & Participant 3 & Participant 4 & Participant 5 & Mean & Rank \\
\hline Establish environmental policies & $3.68 \%$ & $6.46 \%$ & $1.79 \%$ & $12.43 \%$ & $1.06 \%$ & $5.09 \%$ & 8 \\
\hline Identify environmental impacts & $3.10 \%$ & $16.76 \%$ & $5.96 \%$ & $5.10 \%$ & $9.01 \%$ & $7.99 \%$ & 6 \\
\hline Develop environmental concepts & $7.64 \%$ & $7.42 \%$ & $1.08 \%$ & $5.34 \%$ & $20.34 \%$ & $8.36 \%$ & 4 \\
\hline Emergency preparedness and response & $5.08 \%$ & $6.25 \%$ & $9.69 \%$ & $1.05 \%$ & $9.57 \%$ & $6.33 \%$ & 7 \\
\hline Commitment identification & $1.62 \%$ & $3.06 \%$ & $3.04 \%$ & $1.84 \%$ & $9.10 \%$ & $3.73 \%$ & 9 \\
\hline Training and awareness & $2.59 \%$ & $3.68 \%$ & $11.99 \%$ & $1.39 \%$ & $17.83 \%$ & $8.29 \%$ & 5 \\
\hline $\begin{array}{l}\text { Identify environmental objectives and } \\
\text { priorities }\end{array}$ & $8.19 \%$ & $11.36 \%$ & $29.11 \%$ & $9.05 \%$ & $8.07 \%$ & $13.16 \%$ & 3 \\
\hline Cost-efficiency & $44.54 \%$ & $23.72 \%$ & $22.22 \%$ & $36.30 \%$ & $5.30 \%$ & $26.42 \%$ & 1 \\
\hline High quality services & $23.57 \%$ & $21.29 \%$ & $11.11 \%$ & $27.51 \%$ & $19.71 \%$ & $20.64 \%$ & 2 \\
\hline
\end{tabular}

Table 14 illustrates two types of ranking based on the weights

Rank 1: is to compare between sub-criteria in the same criterion. The criteria of energy consumption and environmental risk management have higher priority than others in their group. 
Rank 2: is to compare sub-criteria in 5 levels. To conduct this ranking, the weights are calculated for the total weights of all sub criteria to be equal to $100 \%$. Accordingly, the criteria are ranked with the highest priority of energy consumption criterion.

Table 14. The comparison solution of sub-criteria in level 4 of decision hierarchy

\begin{tabular}{|c|c|c|c|c|}
\hline Criteria & Mean & Rank 1 & Weight & Rank 2 \\
\hline Develop Environmental concepts & $8.36 \%$ & & $56.93 \%$ & \\
\hline Identify categories of environmental pollution & $1.91 \%$ & 3 & $12.98 \%$ & 5 \\
\hline Waste management & $2.35 \%$ & 2 & $15.97 \%$ & 4 \\
\hline Energy consumption & $\mathbf{4 . 1 1 \%}$ & $\mathbf{1}$ & $\mathbf{2 7 . 9 8 \%}$ & $\mathbf{1}$ \\
\hline Emergency preparedness and response & $6.33 \%$ & & $43.07 \%$ & \\
\hline Minimize environmental damages & $2.89 \%$ & 2 & $19.64 \%$ & 3 \\
\hline Environmental risk management & $\mathbf{3 . 4 4 \%}$ & $\mathbf{1}$ & $\mathbf{2 3 . 4 3 \%}$ & $\mathbf{2}$ \\
\hline
\end{tabular}

\subsection{Score calculation}

The next step is to calculate alternatives' scores. Like the criteria weights, the port performance scores are also evaluated by participants; then the score is obtained as the average of participants' evaluations. The group of ports is evaluated for each criterion and sub criterion. The overall score for each port in the group is calculated by the following formula:

$$
\sum_{i=1}^{5} W_{i} \times f_{i}\left(x_{i}\right)
$$

As shown by Table 15, with $69.31 \%$, London port has the best performance in sustainability compared to the other ports. 
Table 15. Relative scores of UK ports

\begin{tabular}{|c|c|c|c|c|c|c|}
\hline Criteria & $\begin{array}{l}\text { Grimsby and } \\
\text { Immingham }\end{array}$ & London & $\begin{array}{c}\text { Milford } \\
\text { Haven }\end{array}$ & Southampton & $\begin{array}{c}\text { Tees and } \\
\text { Hartlepool }\end{array}$ & $\begin{array}{c}\text { Weights of criteria } \\
\left(\mathrm{W}_{\mathrm{i}}\right)\end{array}$ \\
\hline Environmental aspect & $18.46 \%$ & $37.00 \%$ & $20.08 \%$ & $9.43 \%$ & $15.02 \%$ & $52.95 \%$ \\
\hline Establish environmental policies & $17.75 \%$ & $38.32 \%$ & $18.46 \%$ & $9.36 \%$ & $16.12 \%$ & $5.09 \%$ \\
\hline Identify environmental impacts & $14.28 \%$ & $39.53 \%$ & $18.77 \%$ & $7.67 \%$ & $19.76 \%$ & $7.99 \%$ \\
\hline Develop environmental concepts & $14.58 \%$ & $33.45 \%$ & $25.27 \%$ & $10.76 \%$ & $15.95 \%$ & $8.36 \%$ \\
\hline Identify categories of environmental pollution & $14.29 \%$ & $35.53 \%$ & $19.83 \%$ & $9.68 \%$ & $20.67 \%$ & $1.91 \%$ \\
\hline Waste management & $15.36 \%$ & $35.36 \%$ & $23.68 \%$ & $8.89 \%$ & $16.70 \%$ & $2.35 \%$ \\
\hline Energy consumption & $15.00 \%$ & $27.00 \%$ & $32.63 \%$ & $15.09 \%$ & $10.27 \%$ & $4.11 \%$ \\
\hline Emergency preparedness and response & $23.04 \%$ & $35.48 \%$ & $16.72 \%$ & $12.92 \%$ & $11.85 \%$ & $6.33 \%$ \\
\hline Minimize environmental damages & $18.14 \%$ & $36.56 \%$ & $17.61 \%$ & $13.57 \%$ & $14.12 \%$ & $2.89 \%$ \\
\hline Environmental risk management & $27.15 \%$ & $35.30 \%$ & $14.71 \%$ & $12.37 \%$ & $10.46 \%$ & $3.44 \%$ \\
\hline Commitment identification & $29.84 \%$ & $30.19 \%$ & $11.83 \%$ & $7.88 \%$ & $20.25 \%$ & $3.73 \%$ \\
\hline Training and awareness & $21.14 \%$ & $34.93 \%$ & $23.96 \%$ & $10.34 \%$ & $9.63 \%$ & $8.29 \%$ \\
\hline Identify environmental objectives and priorities & $18.85 \%$ & $39.24 \%$ & $17.56 \%$ & $9.65 \%$ & $14.71 \%$ & $13.16 \%$ \\
\hline Economic aspect & $25.35 \%$ & $28.36 \%$ & $13.84 \%$ & $20.40 \%$ & $12.05 \%$ & $47.05 \%$ \\
\hline Cost-efficiency & $32.95 \%$ & $24.21 \%$ & $15.43 \%$ & $13.86 \%$ & $13.55 \%$ & $26.42 \%$ \\
\hline High quality services & $18.32 \%$ & $27.87 \%$ & $14.47 \%$ & $31.23 \%$ & $8.12 \%$ & $20.64 \%$ \\
\hline Overall score & $46.96 \%$ & $69.31 \%$ & $37.85 \%$ & $31.75 \%$ & $28.83 \%$ & \\
\hline Rank & 2 & 1 & 3 & 4 & 5 & \\
\hline
\end{tabular}




\section{ANALYSIS}

Obviously, the given evaluations depend on the set of weights given to the criteria. Accordingly, sensitivity analysis aims to examine scenarios corresponding to changes in the weights of the criteria. By doing so, we can validate the results using the common knowledge about the different ports. For example, as London ports achieved all the Environmental Certificates, it is intuitively expected that by increasing the environmental aspect, its score will go up.

The main purposes of sensitivity analysis are as follows (Chang et al., 2007):

$>$ Reflect the importance of criteria on port performance.

$>$ Being able to forecast the future changes which are possible to effect on the rank of port performance.

$>$ Determine the criteria which most affect the results.

$>$ Validate the obtained results.

\subsection{Sensitivity Analysis}

A sensitivity analysis is carried on by changes in the weight of each criterion and sub-criterion:

a) The weight of environmental aspect is increased from $53.32 \%$ to $75.55 \%$. Accordingly, the economic aspect weight is decreased. This increasing led to a higher score for London, Milford Haven and Tees \& Hartlepool port with $34.83 \%, 17.78 \%$ and $13.33 \%$, respectively. In addition, there are changes in the ranking of ports; Tees \& Hartlepool overtakes the Southampton to achieve fourth position in the ranking. Figure 9 depicts the result.
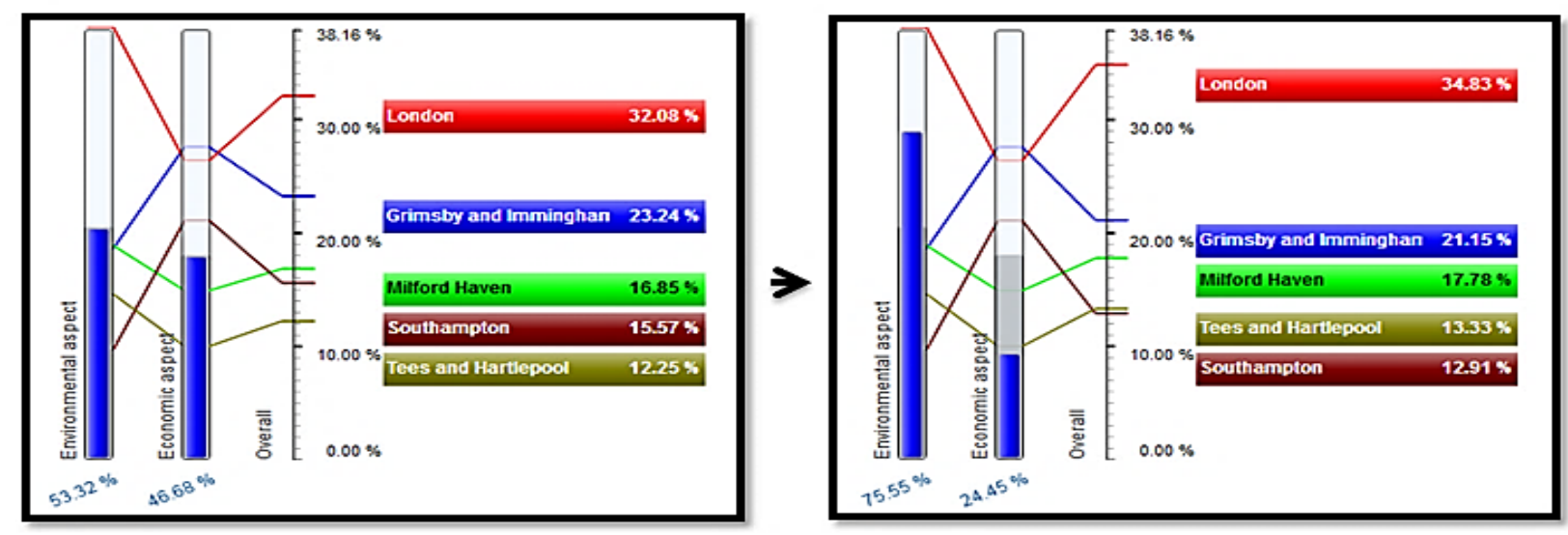

Figure 9. The sensitivity of increase environmental aspect from $53.32 \%$ to $75.55 \%$

Then, gradient analysis which displays the gradient of the ports priority in correspondence to environmental aspect is undertaken As expected, London port's priority increases as the environmental weight increases. Figure 10 depicts this sensitivity analysis. 


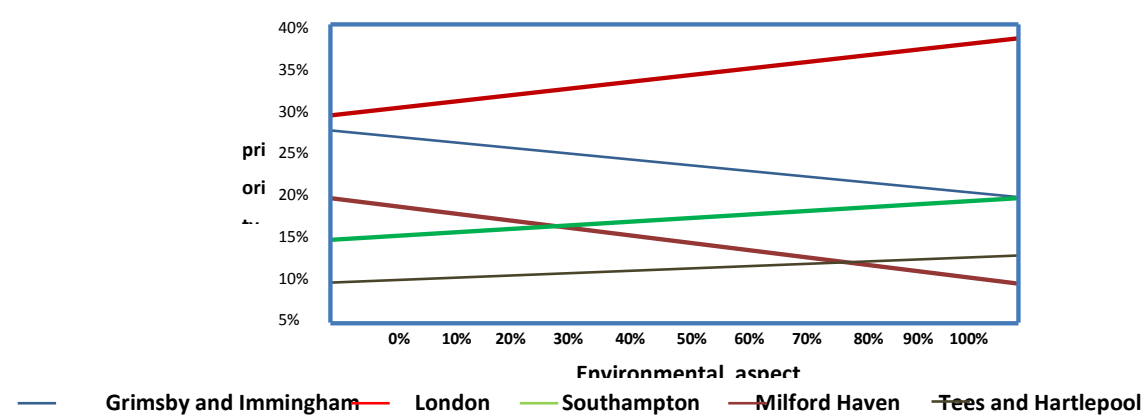

Figure 10. The gradient sensitivity

b) The performance of sensitivity analysis when the criterion of high quality services is increased from $48 \%$ to $87.08 \%$. As London port serves with the highest quality, increasing its weight causes the prioritizing of London port rather than the others. The results are depicted in Figure 11.
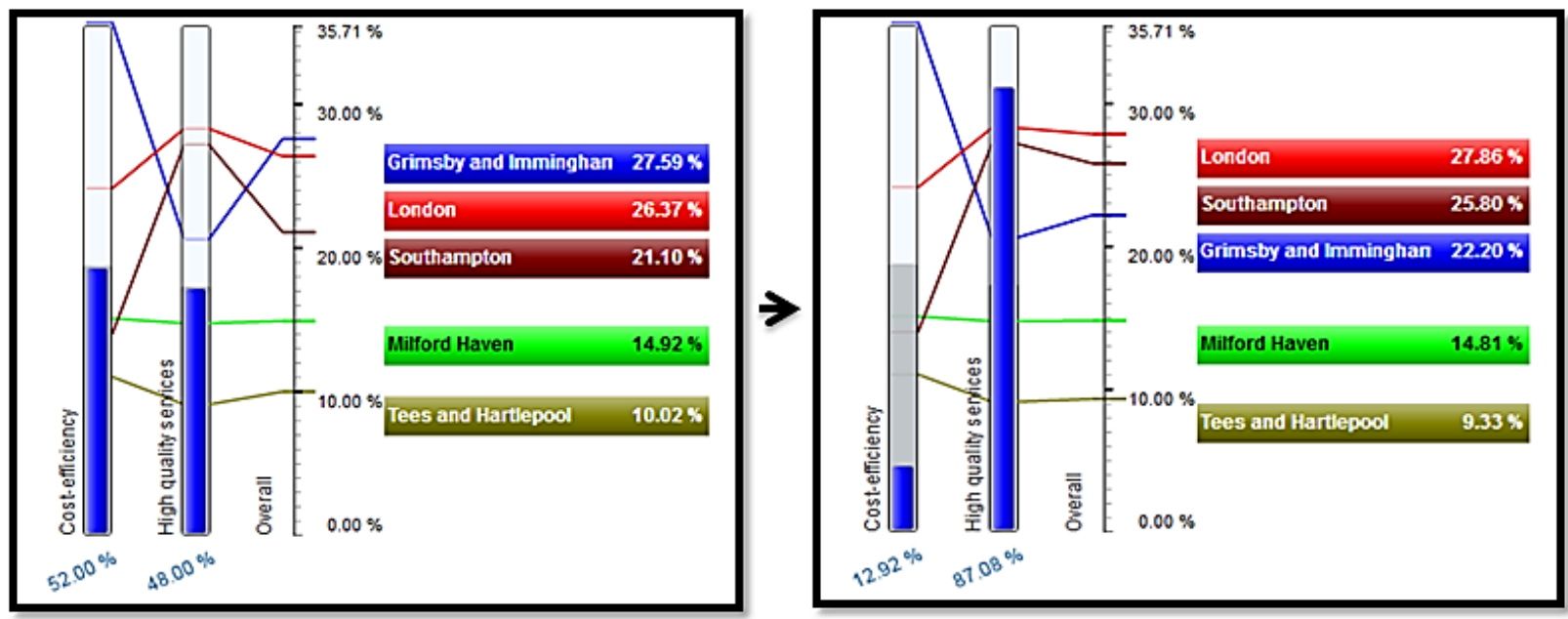

Figure 11. The sensitivity of high quality service from $48 \%$ to $87.08 \%$

\subsection{Discussion}

Based on the gathered data from port managers and experts in maritime supply chain, we rank the largest ports in the UK. Using the sensitivity analysis, we verify the results.

The obtained results of the sensitivity analysis can be summarized based on two aspects:

- Environmental aspect: the results of varying the weights of criteria showed that The London port has always the highest ranking even though the score reduces under effects of the increase of some of the criteria. It can be seen that this port performance achieves stability regarding this aspect. 
- In combination of both aspects: It can be concluded that the rank of port in the sustainability is not changed that much comparing to the initial solution. The position of London port is remained at highest priority for both aspects after sensitivity.

According to the fact that London port invested a lot on environmental sustainability, the evidence of which is receiving different certificates as shown in Table 4, by increasing the weight of environmental aspect, it remains the top ranked port.

The methodology utilized in this research can be extended to the ports other than the studied ones. We provide a general framework, a set of criteria and sub-criteria to study the port sustainability performance considering five major ports in the UK. The outcome of this research can be used as a basis for further development in this area.

\section{CONCLUSION}

A maritime supply chain network is a relatively new concept in the context of supply chain management. This concept is focused on the management of key elements in business with respect to raw material, manufacturing, transportation and distribution. Sustainability includes three dimensions: economic, environmental and social. Regarding the economic aspect, the main objective aims to minimize the costs. The environmental aspect aims to reduce environmental impacts occurred by operations. The last dimension relates to social-related factors in one organization such as: human rights and labor.

In the scope of the project, the 5 largest ports in the UK port system are studied regarding their sustainability performance with respect to environmental and economic aspects. A survey is conducted and 10 logistics experts and port managers were asked to fill it out. Based on the gathered primary data, the multi criteria decision making methodology is applied to evaluate the port performance. Moreover, the AHP method is utilized to select best sustainable port performance among the selected ports.

\subsection{Research limitations}

There are some limitations in this study. First, both of main concepts in this study, maritime supply chain and sustainability, are considered as one topic, sustainable maritime supply chain management. Both concepts are very wide and cover many important elements. Gathering data is not always simple. Normally, there are a few people who know this kind of information in details. Furthermore, the number of participants is limited. Increasing the number of participants will give more precise information. But, note that respondents should be appropriately qualified. Not 
necessarily, increasing the number of respondents increases the accuracy of information. There are, by nature, a limited number of potential respondents within the five ports studied who have the knowledge to fill out the questionnaire accurately. In this study, we have prioritized quality over quantity of response.

\subsection{Future direction}

This study provides a framework for sustainable assessment in maritime supply chain. By providing a set of criteria, it can be applied to measure the sustainable performance of not only ports but also other maritime sectors. There might be a need to change some criteria from a sector to the other, but the general approach would be the same. For instance, the main focus of the study can be expanded to the role of port authorities. Port authorities are the main organization to develop ports and decide towards port sustainability. Thus, the research could be conducted to assess the role of such authorities in development of the UK ports toward sustainability.

Regarding the methodology for ranking the ports, AHP-TOPSIS, as a new weighting method, also can be utilized. The obtaining results can be compared to those from AHP method. Moreover, regarding the fact that major ports are normally from different geographical points, geographical theme can be considered as attributes. Interested readers may find related information in Turner et al. (2014). Furthermore, a scenario from variety of points of view can be considered. For example, Puente-Rodríguez et al. (2014) propose the effect of knowledge management in socio-ecological sustainability achievement.

In addition, the assessment can be expanded from economic and environmental dimension to include the social dimension. Social aspect of sustainability has not been widely considered in the literature of sustainability. This approach can be investigated on other port systems performance.

\section{APPENDICES}

Appendix A:

Table A.1. ISO 14001 standards of environmental management system

ISO 14001 standards of environmental management system

4.1 General

- Establish environmental policies

- Identify the environmental impacts from past, existing and future of port activities

- Description environmental objectives of port management and priorities

- Description of strategies to achieve the environmental objectives which are regarding to economic and environmental dimension.

4.2 Environmental policy 
- Provide the policies statements of the port objectives to all port elements.

4.3 Planning

4.3.1 Environmental dimension:

- Description environmental performance of UK port

- Identify categories of environmental pollution

- Waste management

- Energy consumption

4.3.2 Legal and requirements

- Environmental policies from Port Authority

- Environmental policies form government

- Environmental laws from IMO (international maritime organization)

- Environmental guidance and policies of Annex VI

4.3.3 Objectives and targets

- To achieve a sustainability performance of port from the connection of economic and environmental dimension

4.4 Implementation and operation:

4.4.1 Commitment identification:

- Port manager

- Port director

- Supervisor

- Workers

4.4.2 Awaress and training:

- All staffs have to be upgraded the awareness about sustainability

- Training programs have to separate follow job position and commitment

4.4.3Communication

- Internal communication between all elements in port activities

- External communication under procedure: annual reports, website.

4.5 Operation control

- To conduct surveillance

4.6 Emergency preparedness and response

- To make emergency plan

- To minimize damages for environment

- Training for staffs

4.7 Checking and corrective actions

4.7.1 Monitoring and measurement

- To conduct researches, annual report

- To measure the effectiveness of process follow desired objectives

4.8 Management review

- To evaluate about effectiveness from operation records.

\section{Appendix B:}

A/ Personal details of the participant

1. Your name: 
2. Address:-

3. What is your position at the port:

\section{B/ General view about environmental management at the port:}

In this part, there are some general questions about the sustainable policies in your port

1. Does the port establish or upgrade the "Green policies" annually? Yes/ No / I don't know

2. Does the port have the part of EMS? Yes/ No/I don't know

3. Have the port got Iso 14001 about EMS? If not, does the port have plans to get this certification?

Yes/ No/I don't know

4. Does the port have the part of environmental risk management?

Yes/ No/I don't know

5. Does the port have any activities to reduce environmental damages?

Yes/ No/I don't know

\section{$\mathrm{C} /$ The assessment of the sustainable performance in the Port:}

In this part, I would like to consult you about your evaluation about the sustainable performance in the port follow the set of standards. You can use the indicators from the scale to rank for the list of criteria and sub-criteria below:

Table B.1. Ranking Scale

\begin{tabular}{|l|l|l|l|l|l|l|c|c|}
\hline 1 & 2 & 3 & 4 & 5 & 6 & 7 & 8 & 9 \\
\hline $\begin{array}{l}\text { Equally } \\
\text { important }\end{array}$ & & $\begin{array}{l}\text { More } \\
\text { important }\end{array}$ & & $\begin{array}{l}\text { Strongly } \\
\text { important }\end{array}$ & & $\begin{array}{l}\text { Very } \\
\text { strongly } \\
\text { important }\end{array}$ & & $\begin{array}{l}\text { Extremely } \\
\text { important }\end{array}$ \\
\hline
\end{tabular}

Table B.2. The environmental and economic criteria

\begin{tabular}{|c|c|c|c|c|c|c|c|c|c|}
\hline Criteria & 1 & 2 & 3 & 4 & 5 & 6 & 7 & 8 & 9 \\
\hline $\begin{array}{l}\text { Environmental aspect } \\
\text { 1. Establish environmental policies } \\
\text { 2. Identify environmental impacts } \\
\text { 3. Environmental objectives and } \\
\text { priorities } \\
\text { 4. Environmental dimension } \\
\text { 5. Commitment identification } \\
\text { 6. Training and awareness }\end{array}$ & & & & & & & & & \\
\hline
\end{tabular}




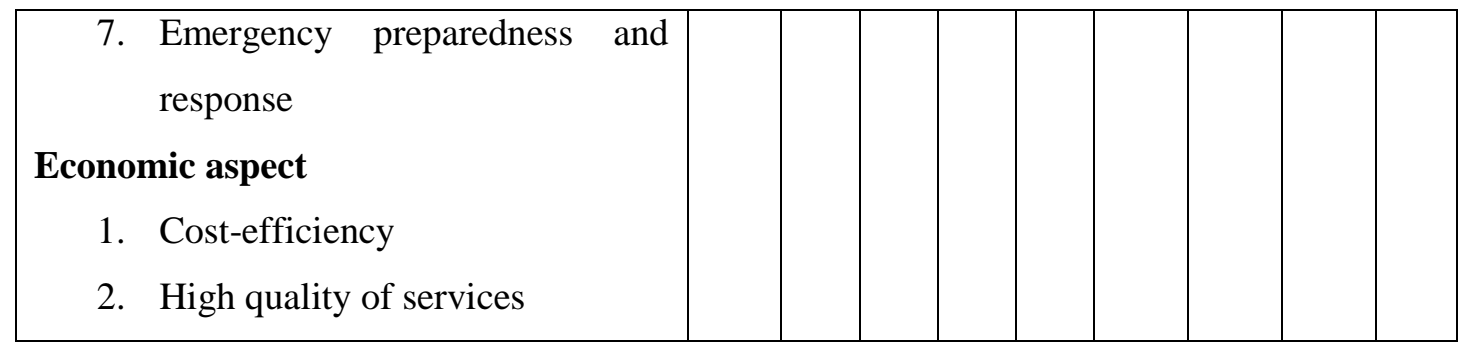

Table B.3. The environmental sub-criteria I

\begin{tabular}{|c|c|c|c|c|c|c|c|c|c|}
\hline Sub-criteria & $\mathbf{1}$ & $\mathbf{2}$ & $\mathbf{3}$ & $\mathbf{4}$ & $\mathbf{5}$ & $\mathbf{6}$ & $\mathbf{7}$ & $\mathbf{8}$ & $\mathbf{9}$ \\
\hline $\begin{array}{l}\text { 4.1 Identify categories of } \\
\text { environmental } \\
\text { pollution }\end{array}$ & $\square$ & $\square$ & $\square$ & $\square$ & $\square$ & $\square$ & $\square$ & $\square$ & $\square$ \\
4.2 Waste management & $\square$ & $\square$ & $\square$ & $\square$ & $\square$ & $\square$ & $\square$ & $\square$ & $\square$ \\
4.3 Energy consumption & $\square$ & $\square$ & $\square$ & $\square$ & $\square$ & $\square$ & $\square$ & $\square$ & $\square$ \\
& & & & $\square$ & & & & & \\
\end{tabular}

Table B.4. The environmental sub-criteria II

\begin{tabular}{|c|c|c|c|c|c|c|c|c|c|}
\hline Sub-criteria & 1 & 2 & 3 & 4 & 5 & 6 & 7 & 8 & 9 \\
\hline $\begin{array}{l}\text { 7.1. To minimize } \\
\text { damages for } \\
\text { environment }\end{array}$ & $\square$ & $\square$ & $\square$ & $\square$ & $\square$ & $\square$ & $\square$ & $\square$ & $\square$ \\
\hline $\begin{array}{l}\text { 7.2. Environmental } \\
\text { risk management }\end{array}$ & $\square$ & $\square$ & $\square$ & $\square$ & $\square$ & $\square$ & $\square$ & $\square$ & $\square$ \\
\hline
\end{tabular}

1: Less important, 5: extremely important 
Table B.5. Port ranking based on environmental aspect

\begin{tabular}{|l|l|l|l|l|l|l|}
\hline \multicolumn{1}{|c|}{ Criteria } & $\begin{array}{c}\text { Environ } \\
\text { mental } \\
\text { policies }\end{array}$ & $\begin{array}{c}\text { Environment } \\
\text { al impacts }\end{array}$ & $\begin{array}{c}\text { Environmental } \\
\text { objectives and } \\
\text { priorities }\end{array}$ & $\begin{array}{c}\text { Environme } \\
\text { ntal content } \\
\text { (program) }\end{array}$ & $\begin{array}{c}\text { Commitment } \\
\text { identification }\end{array}$ & $\begin{array}{c}\text { Training } \\
\text { and } \\
\text { awareness }\end{array}$ \\
\hline $\begin{array}{l}\text { Grimsby and } \\
\text { Immingham }\end{array}$ & & & & & & \\
\hline London & & & & & & \\
\hline Milford Haven & & & & & & \\
\hline Southampton & & & & & & \\
\hline $\begin{array}{l}\text { Tees and } \\
\text { Hartlepool }\end{array}$ & & & & & & \\
\hline
\end{tabular}

Table B.6. Port ranking based on economic aspect

\begin{tabular}{|l|l|l|l|l|}
\hline \multicolumn{1}{|c|}{ Criteria } & Emergency & $\begin{array}{c}\text { Emergency } \\
\text { preparedness }\end{array}$ & Cost-efficiency & High quality of services \\
\hline Grimsby and Immingham & & & & \\
\hline London & & & & \\
\hline Milford Haven & & & & \\
\hline Southampton & & & & \\
\hline Tees and Hartlepool & & & & \\
\hline
\end{tabular}

Table B.7. Port ranking based on environmental sub-criteria I

\begin{tabular}{|l|l|l|l|}
\hline \multicolumn{1}{|c|}{ Sub-criteria } & $\begin{array}{c}\text { Environmental pollution } \\
\text { measurement }\end{array}$ & $\begin{array}{c}\text { Waste } \\
\text { management }\end{array}$ & Energy consumption \\
\hline Grimsby and Immingham & & & \\
\hline London & & & \\
\hline Milford Haven & & & \\
\hline Southampton & & & \\
\hline Tees and Hartlepool & & & \\
\hline
\end{tabular}

Table B.8. Port ranking based on environmental sub-criteria II

\begin{tabular}{|l|l|l|}
\hline \multicolumn{1}{|c|}{ Sub-criteria } & Environmental damages reducing & Environmental risk management \\
\hline Grimsby and Immingham & & \\
\hline London & & \\
\hline Milford Haven & & \\
\hline Southampton & & \\
\hline Tees and Hartlepool & & \\
\hline
\end{tabular}

\section{Appendix C:}

Table C.1. The environmental criteria and indicators

\begin{tabular}{|l|ll|}
\hline Environmental criteria & \multicolumn{1}{c|}{ Indicators } \\
\hline 1. Establish environmental policies & 1. Green policies \\
2. Identify environmental impacts & 2. The level of impacts in port area \\
& & $1=$ low, $3=$ high
\end{tabular}




\section{Environmental objectives and priorities \\ 4. Environmental dimension \\ 4.1. Identify categories of environmental pollution}

4.2. Waste management

\subsection{Energy consumption}

5. Commitment identification

6. Training and awareness

a. All staffs are educated and trained about sustainability

7. Emergency preparedness and response

7.1. To minimize damages of environment

7.2. Environmental risk management
4.1.1 Air pollution $\left(\mathrm{CO}_{2}\right.$ Equivalent tonnes) 4.1.2 Noise pollution

4.1.3 Water pollution

4.2.1 Solid waste (tonnes)

4.2.2 liquid waste (tonnes)

4.3.1 Fuel consumption ( $\%$ of total energy)

4.3.2 Electricity consumption $(\mathrm{kWh})$

5.1 The sum of levels of environmental commitment in the organization.

1 = low, 3 = high

6.1 environmental certificates

7.1 To be measured by level of environmental damages in port areas.

7.2 The sum of hazard levels from environmental exposures

Table C.2. The economic criteria and indicators

\begin{tabular}{|c|c|}
\hline Economic criteria & Indicators \\
\hline 1. Cost-efficiency & $\begin{array}{l}\text { 1.1. Transportation cost (£/TEU) } \\
\text { 1.2. Fuel cost }(£ / \text { ton }) \\
\text { 1.3. Electricity cost }(£ / k W h) \\
\text { 1.4. Shipping cost }(£ / \text { TEU })\end{array}$ \\
\hline 2. High quality of services & $\begin{array}{l}\text { 2.1 Port congestion (days delay) } \\
\text { 2.2 Loading and unloading cost } \\
\text { (£/1000lbs) } \\
\text { 2.3 Infrastructure } \\
\text { 2.4 Service and waiting time (hours/ } \\
\text { ship) }\end{array}$ \\
\hline
\end{tabular}

\section{REFERENCES}

Asgari N, Farahani RZ, Goh M. Network design approach for hub ports-shipping companies competition and cooperation. Transportation Research Part A: Policy and Practice 2013; 48 118. 
Asteris $\mathrm{M}$, Collins $\mathrm{A}$. UK container port investment and competition: impediments to the market. Transport Reviews 2010; 30 (2) 163-178.

Banomyong R. The impact of port and trade security initiatives on maritime supply chain management. Maritime Policy and Management: The Flagship Journal of International Shipping and Port Research 2005; 32(1) 3-13.

Bichou K, Gray R. A logistics and supply chain management approach to port performance management. Maritime Policy \& Management: The flagship journal of international shipping and port research 2004; 31(1) 47-67.

Carter CR, Rogers DS. A framework of sustainable supply chain management: moving toward new theory. International Journal of Physical Distribution \& Logistics Management 2008; 38(5) 360387.

Chang CW, Wu CR, Lin CT, Chu HC. An application of AHP and sensitivity analysis for selecting the best slicing. Computers \& Industrial Engineering 2007; 52(2) 296-307.

Denktas-Sakar G, Karatas-Cetin C. Port Sustainability and Stakeholder Management in Supply Chains: A Framework on Resource Dependence Theory. The Asian Journal of Shipping and Logistics 2012; 28(3) 301-319.

Fitzgerald WB, Howitt OJA, Smith IJ. Greenhouse gas emissions from the international maritime transport of New Zealand's imports and exports. Energy Policy 2011; 39(3) 1521-1531.

Gibbs D, Rigot-Muller P, Mangan J, Lalwan C. The role of sea ports in end-to-end maritime transport chain emissions. Energy Policy 2014; 64 337-348.

Gilman S. Sustainability and national policy in UK port development. Maritime Policy \& Management: The flagship journal of international shipping and port research 2003; 30(4) 275291.

Goulielmos AM. European policy on port environmental protection. Global Nest 2000; 2(2) 189-197.

Harrison A, Hoek RV. Logistics management and strategy competing through the supply chain, 2008. 3rd Edition. Essex: Pearson Education Limited.

Le XQ, Vu VH, Hens L, Heur BV. Stakeholder perceptions and involvement in the implementation of EMS in ports in Vietnam and Cambodia. Journal of Cleaner Production 2014; 64 1-21.

Lu CS, Shang KC, Lin CC. Identifying crucial sustainability assessment criteria for international ports, 2012.

Marlow PB, Casaca AC. Measuring lean ports performance. International Journal of Transport Management 2003; 1(4) 189-202. 
Mendoza GA, Prabhu R. Multiple criteria decision making approaches to assessing forest sustainability using criteria and indicators: a case study. Forest Ecology and Management 2000; 131(1) 107-126.

Peris-Mora E, Diez Orejas J, Subirats A, Ibanez S, Alvarez P. Development of a system of indicators for sustainable. Marine Pollution Bulletin 2005; 50 1649-1660.

Permala A. Tranport and logistics developments. Retrieved from a freight, 2009; http://www.efreightproject.eu/knowledge/defaultinfo. aspx?areaid=28\&index=2.

Puente-Rodríguez D, Giebels D, Jonge VND. Strengthening coastal zone management in the Wadden Sea by applying 'knowledge-practice interfaces. Ocean \& Coastal Management 2014.

Ramanathan R. A note on the use of the analytic hierarchy process for environmental impact assessment. Journal of Environmental Management 2001; 63(1) 27-35.

Saaty TL. What is the Analytic Hierarchy Process? Eds. Mitra G, Greenberg HJ, Lootsma FA, Rijkaert MJ, Zimmermann HJ. Mathematical Models for Decision Support 1988; 48 109-121.

Saengsupavanich C, Coowanitwong N, Gallardo WG, Lertsuchatavanich C. Environmental performance evaluation of an industrial port and estate: ISO14001, port state control-derived indicators. Journal of Cleaner Production 2009; 17(2) 154-161.

Song DW, Lee PTW. Maritime logistics in the global supply. International Journal of Logistics Research and Applications: A Leading journal of supply chain management 2009; 12(2) 83-84.

Song DW, Panayides PM. Maritime logistics: A complete guide to effective shipping and port management 2012. London, Kogan Page.

Turner RK, Lorenzoni I, Beaumont N, Bateman IJ, Langford IH, Mcdonald AL. Coastal management for sustainable development: analysing environmental and socio-economic changes on the UK coast. Geographical Journal 1998; 164(3) 269-281.

Verhoeven P. A review of port authority functions: towards a renaissance? Maritime Policy \& Management: The flagship Journal of International Shipping and Port Research 2010; 37(3) 247 270.

Villalba G, Gemechu ED. Estimating GHG emissions of marine ports - the case of Barcelona. Energy Policy 2011; 39(3) 1363-1368.

Wooldridge CF, McMullen C, Howe V. Environmental management of ports and harboursimplementation of policy through scientific monitoring. Marine Policy 1999; 23(4) 413- 425.

\section{WEB REFERENCES}

Brief History of IMO. http://www.imo.org/About/HistoryOfIMO/Pages/Default.aspx 
Environmental Management System. http://www.pla.co.uk/Environment/EnvironmentalManagement-System

Environmental Performance Report, 2012.

ESPO/Ecoports. http://www.ecoports.com/about

GOV.UK. 2013: https://www.gov.uk/government/policies/sustaining-a-thriving-maritime-sector

Green London gateway to open in 2013. http://www.greenport.com/news101/europe/greenlondon-gateway-to-open-in-2013

Grimsby. http://www.abports.co.uk/Our_Locations/Grimsby_Immingham/Grimsby/

Immingham. http://www.abports.co.uk/Our_Locations/Grimsby_Immingham/Immingham/

IMO Announces Development of Sustainable Maritime Development Goals. http://post2015.iisd.org/news/imo-announces-development-of-sustainable-maritimedevelopment-goals/

PD Ports A Brookfield Ports Company . http://www.pdports.co.uk/en/footer/enviroment/ Port of London Authority, 2013.

Port of Southampton The UK's most dynamic maritime gateway, 2013.

Q\&A: Liquefied natural gas. http://news.bbc.co.uk/2/hi/uk_news/wales/7881388.stm

Sustainable Development. http://www.abports.co.uk/Sustainable_Development/

Teesport and hartelpool port handbook, 2013. Land \& Marine Publications Ltd.

UK Tankship Port Gets EcoPorts PERS Certification. http://www.marinelink.com/news/certificationtankship344654.aspx

World Maritime Day 2013: "Sustainable Development: IMO's contribution beyond Rio+20". http://www.imo.org/MediaCentre/PressBriefings/Pages/40-WMD.aspx

World Shipping Council: http://www.worldshipping.org/about-the-industry/global-trade/ 